\title{
ANTIBACTERIAL ACTIVITY AND GAS CHROMATOGRAPHY-MASS SPECTROMETRY STUDIES OF ALGERIAN ATRIPLEX HALIMUS L.
}

\author{
ZIANE L ${ }^{1 *}$, DJELLOULI ${ }^{2}$, MILOUDI ${ }^{3}$ \\ ${ }^{1}$ Laboratory of Chemistry and Science Environment, University of Bechar, Algeria. ${ }^{2}$ Laboratory of Valorization of Vegetal Resource and \\ Food Security in Semiarid Areas, South West of Algeria, University of Béchar, Béchar, Algeria. ${ }^{3}$ Department of Chemistry, Laboratory of \\ Chemistry, University of Béchar, Béchar, Algeria. Email: 1.ziane@yahoo.fr
}

Received: 16 December 2019, Revised and Accepted: 11 January 2020

ABSTRACT

Objective: The objective of the study was to find out the antibacterial efficacy and identify the main constituents of the essential oil of Atriplex halimus from southwest of Algeria.

Methods: The essential oil from the aerial parts of the endemic plant A. halimus (saltbush in English, qataf in Arabic) collected from the region of Sahara southwest of Algeria was isolated by hydrodistillation and analyzed by gas chromatography-mass spectrometry. Antibacterial potency of essential oil from this plant has been tested against Staphylococcus aureus (ATCC 29213), Escherichia coli (ATCC 25922), and Bacillus cereus (ATCC11778) by disk diffusion assay.

Results: The essential oil revealed the presence of 14 components, the dominant compounds arecadina-1(10), 4-diene (10.69\%), germacrene D (9.79\%), octane (9.37\%), pelargonaldehyde (9.06\%), 3-Furancarboxaldehyde (6.87\%), $\beta$-pinene (2.6\%), camphene (2.59\%), and myrcene (2.10\%). The essential oil exhibits very effective antimicrobial activity using disk diffusion assay method with minimum inhibitory concentration ranging from $0.82 \mu \mathrm{l} / \mathrm{ml}$ to $2.4525 \mu \mathrm{l} / \mathrm{ml}$.

Conclusions: This result showed that this native plant may be a good candidate for further biological and pharmacological investigations.

Keywords: Essential oil, Atriplex halimus, Antimicrobial activity, Gas chromatography-mass spectrometry analysis.

(C) 2020 The Authors. Published by Innovare Academic Sciences Pvt Ltd. This is an open access article under the CC BY license (http://creativecommons. org/licenses/by/4. 0/) DOI: http://dx.doi.org/10.22159/ajpcr.2020.v13i3.36638

\section{INTRODUCTION}

Atriplexspecies of the family Amaranthaceae(formerly Chenopodiaceae) are among the few salt-tolerant plants which collected the salt lands in bladder cells situated on leaf surfaces and subsequently excreted by the bursting of these cells [1,2]. Atriplex halimus is an evergreen shrub which can grow $2 \mathrm{~m}$ high and $3 \mathrm{~m}$ diameter at a medium rate. It is a monoecious plant that is pollinated by wind and produces a staminate flower [3]. It is widely distributed in Europe and Northern Africa, including the Sahara in Morocco and Algeria [4] (Fig. 1).

A. halimus is used as fodder reserves and as a supplementary forage resource in arid and semi-arid countries [5]. The ensiling A. halimus as a browse forage showed comparable results to polyethylene glycol (PEG) supplementation and might be easier and might lower feeding cost than daily PEG supplementation [6].

A. halimus plants accumulate large amounts of $\mathrm{Cd}$ in their tissues (predominance in roots), suggesting the possibility of their use in decontaminating saline soils polluted by $\mathrm{Cd}$ [7].

In Algeria and in particular, the Sahara part, the plant is used by Bedouin for feeding their sheep and goats [4], and in popular folk remedy, it is used to treat diabetes, stomach pains, chest ailments, muscular pain, and intestinal worms and to regulate gallbladder excretions.

Regarding the chemical composition of this species, and to the best of our knowledge, few chemical compositions have been reported in the literature $[8,9]$. In these papers, authors describe the isolation of some phenolic compounds, including flavonoids. We report herein the chemical composition of the essential oil of $A$. halimus growing in Algeria, and some carried antibacterial activities.

\section{METHODS}

Plant material

The aerial parts (leaves and stems) of A. halimus were collected in March 2016 from the region of Bechar, Algeria and identified. A voucher specimen was deposited at the Herbarium of the Valorization of Resource and Food Security in Semiarid Areas Laboratory, South West of Algeria, University of Bechar $[10,11]$.

\section{Extraction of essential oil}

The dried aerial parts of A. halimus ( $1 \mathrm{~kg}$ ) were subjected to hydrodistillation for $5 \mathrm{~h}$ in 3 times using a Clevenger-type apparatus, according to the method outlined by the European Pharmacopoeia [12]. The essential oil was then separated from the aqueous layer, dried over anhydrous sodium sulfate. The calculated average of essential oil yield is $0.0475 \%$. The essential oil was stored in sealed vials at low temperature $\left(4^{\circ} \mathrm{C}\right)$ until $(\mathrm{GC}-\mathrm{MS})$ analysis.

\section{GC-MS analysis}

The GC-MS analysis was performed using a Hewlett Packard Agilent 6890 GC system coupled with a 5973C MS. HP-5 MS analytical fused silica capillary column $(60 \mathrm{~m} \times 0.25 \mathrm{~mm} \times 0.25 \mu \mathrm{m}$, Agilent, Santa Clara, CA) was used for chromatographic separations. For both columns, the oven temperature had ramped from $60^{\circ} \mathrm{C}$ to $250^{\circ} \mathrm{C}(8 \mathrm{~min})$ at $2^{\circ} \mathrm{C} / \mathrm{min}$ isothermal for $10 \mathrm{~min}$. The flow rate of the helium was $0.5 \mathrm{~mL} / \mathrm{min}$. The retention indices for all components were determined according to the method using n-alkanes as standard.

\section{Identification of components}

Individual peaks were identified by comparing their Kovats index relative to n-alkanes (C8-C29) obtained by a non-polar HP-5MS column provided in the literature running at the same conditions used for the 
Table 1: Chemical composition of the essential oil of Atriplex halimus

\begin{tabular}{|c|c|c|c|c|c|}
\hline Peak & RT & Name of compound & Formula & Area (\%) & $\mathbf{R I}$ \\
\hline 1. & 4.713 & Octane & $\mathrm{C}_{8} \mathrm{H}_{18}$ & 9.37 & $80,057,554$ \\
\hline 2. & 5.028 & 3-Furancarboxaldehyde & $\mathrm{C}_{5} \mathrm{H}_{4} \mathrm{O}_{2}$ & 6.87 & $80,964,029$ \\
\hline 3. & 5.628 & 2-vinyl-5-methylfuran & $\mathrm{C}_{7} \mathrm{H}_{8} \mathrm{O}^{2}$ & 2.16 & $82,690,648$ \\
\hline 4. & 6.239 & 1,1,4-Trimethylcyclohexane & $\mathrm{C}_{9} \mathrm{H}_{18}$ & 3.83 & $84,448,921$ \\
\hline 5. & 11.366 & Camphene & $\mathrm{C}_{10} \mathrm{H}_{16}^{18}$ & 2.59 & $95,333,556$ \\
\hline 6. & 12.812 & $\beta$-Pinene & $\mathrm{C}_{10}^{10} \mathrm{H}_{16}^{16}$ & 2.6 & $97,745,163$ \\
\hline 7. & 13.612 & Myrcene & $\mathrm{C}_{10} \mathrm{H}_{16}^{16}$ & 2.1 & $99,079,386$ \\
\hline 9. & 21.641 & Pelargonaldehyde & $\mathrm{C}_{9} \mathrm{H}_{18} \mathrm{O}$ & 9.06 & $11,058,323$ \\
\hline 10. & 25.456 & p-Menthan-3-one, cis-p- & $\mathrm{C}_{10} \mathrm{H}_{18}^{18} \mathrm{O}$ & 2.88 & $11,590,624$ \\
\hline 11. & 32.845 & Thiophene,2-[(methylthio)ethynyl] & $\mathrm{C}_{10}^{10} \mathrm{H}_{16}^{18} \mathrm{O}$ & 3.11 & $12,647,435$ \\
\hline 12. & 36.051 & Unknown & & 8.29 & $13,119,705$ \\
\hline 13. & 46.991 & Germacrene D & $\mathrm{C}_{15} \mathrm{H}_{24}$ & 9.79 & $14,845,492$ \\
\hline 14. & 48.991 & Myristicin & $\mathrm{C}_{11}^{15} \mathrm{H}_{12}^{24} \mathrm{O}_{3}$ & 4 & $15,179,931$ \\
\hline 15. & 49.374 & Cadina-1(10),4-diene & $\mathrm{C}_{15} \mathrm{H}_{24}{ }^{12}$ & 10.69 & $15,245,626$ \\
\hline 16. & 59.193 & Unknown & & 8.59 & $16,981,887$ \\
\hline \multicolumn{3}{|c|}{ Number of identified compounds } & & 14 & \\
\hline \multicolumn{3}{|c|}{ Monoterpene hydrocarbons } & & 23.73 & \\
\hline \multicolumn{3}{|c|}{ Oxygenated monoterpenes } & & 32.62 & \\
\hline \multicolumn{3}{|c|}{ Sesquiterpene hydrocarbons } & & 15.94 & \\
\hline \multicolumn{3}{|c|}{ Others compounds } & & 19.65 & \\
\hline \multicolumn{3}{|c|}{ Percentage of identified compound } & & 91.94 & \\
\hline
\end{tabular}

RI: Retention indices relative to C8-C29 n-alkanes on the HP-5MS column; RT: Retention time

Table 2: Antimicrobial activity of essential oils from the aerial parts of Atriplex halimus

\begin{tabular}{ll}
\hline Organisms & Minimum inhibitory concentration $(\boldsymbol{\mu l} / \mathbf{m l})$ \\
\hline Escherichia coli & 1.64 \\
Staphylococcus aureus & 2.4525 \\
Bacillus cereus & 0.82 \\
\hline
\end{tabular}

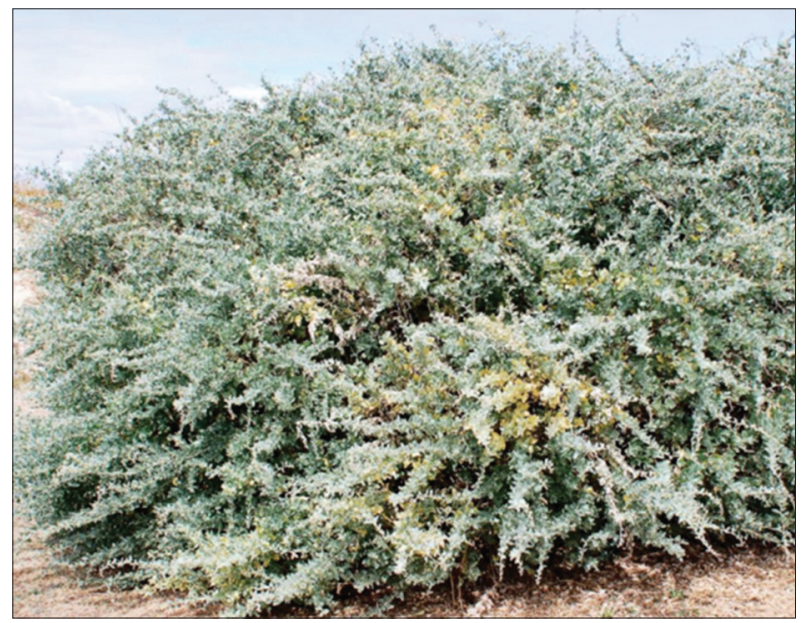

Fig. 1: Photograph of Atriplex halimus [4]

essential oils and by comparing their mass spectral fragmentation patterns using NIST08 library spectra database [13].

\section{Antibacterial activity}

The disk diffusion method was used to screen for antibacterial activities of the crude extracts against the four bacterial strains, namely, Staphylococcus aureus (ATCC 29213, positive control: Penicillin), Escherichia coli (ATCC 25922, positive control: Gentamycin sulfate injection), and Bacillus cereus (ATCC11778). The Petri dishes were maintained by serial subculturing every month on nutrient agar slants and incubating at $37^{\circ} \mathrm{C}$ for $18-24 \mathrm{~h}$. The minimum inhibitory concentrations (MICs) of the extracts were determined using a serial microplate dilution assay against each test bacterial species.

\section{RESULTS AND DISCUSSION}

\section{Essential oil analysis}

The yield of the essential oil (light yellow color) obtained by hydrodistillation of A. halimus was $0.0475 \%$, and a total of 17 different volatile and semi-volatile compounds were identified (Table 1), distributed by distinct chemical classes: Oxygenated monoterpenes (32.62\%), sesquiterpene hydrocarbons (15.94\%), monoterpene hydrocarbons $(23.73 \%)$, and sulfur compounds (3.11\%). Nearly $20 \%$ of the oil composition is unknown, which might be due to insufficient information about their RI in literature.

The number of components identified in the essential oil of $A$. halimus is 14 which accounted for $91.94 \%$ of the total components. Their retention indices and relative percentages are shown in Table 1. The dominant constituents identified in the sample are cadina-1(10)4-diene $(10.69 \%)$ [14], germacrene D $(9.79 \%)$ [15], octane (9.37\%) [14], pelargonaldehyde (9.06\%) [16], and 3-Furancarboxaldehyde (6.87\%) [17]. Other minor constituents of the oil are myristicin (4.00\%) [18], 1,1,4-Trimethylcyclohexan (3.83\%), $\alpha$-terpinene $(3.24 \%)$ [19], Thiophene,2-[(methylthio) ethynyl] (3.11\%) [18], p-Menthan-3-one, cis-p- (2.88\%) [14], $\beta$-Pinene (2.60\%) [15], camphene (2.59\%) [18], 2-vinyl-5methylfuran (2.16\%) [16], and myrcene $(2.10 \%)$ [18]. These qualitative and quantitative differences in the chemical composition of essential oils could be attributed to several factors such as geographical location, the climatic effects, harvest season, nature of the soil, age of the plant parts, the state of used plant materials (dried or fresh), the part of the plant used, time of collection, and chemotype $[20,21]$.

\section{Antibacterial activity}

The results obtained for antibacterial activity screening of $A$. halimus essential oil are summarized in Table 2 . With the broth dilution method, the MIC values for essential oil of aerial parts were in the range of $0.82-$ $2.4525 \mu \mathrm{l} / \mathrm{ml}$

The essential oil of A. halimus was found to have moderate to high antimicrobial activity. It showed strong inhibition against $B$. cereus and low activity against $S$. aureus. This antimicrobial activity may be due to the chemical composition of the essential oil, which is rich in oxygenated monoterpenes. 


\section{CONCLUSIONS}

This paper presents an interesting analysis of the chemical composition of the aerial parts essential oil of A. halimus. Among the 14 components identified, cadina-1(10)4-diene (10.69\%), germacrene D (9.79\%), octane $(9.37 \%)$, and pelargonaldehyde $(9.06 \%)$ were the main components. The antibacterial activity of $A$. halimus oil displayed a significant effect among the different bacterial strains.

\section{ACKNOWLEDGMENTS}

I acknowledged the director of the Scientific and Technical Research Center in Physico-Chemical Analysis. BP 248 Algiers RP 16004 Algiers.

\section{AUTHORS' CONTRIBUTIONS}

The author declares that this work was done by the author named in this article.

\section{CONFLICTS OF INTEREST}

We declare that we have no conflicts of interest.

\section{REFERENCES}

1. Mozafar A, Goodin JR. Vesiculated hairs: A mechanism for salt tolerance in Atriplex halimus L. Plant Physiol 1970;45:62-5.

2. Wong CH, Jager HJ. Salt-induced vesiculation in mesophyll cells of Atriplex species. Plant Sci Lett 1978;12:63-8.

3. Romera P, Fernández-Illescas F, Nieva FJ, Rodríguez-Rubio P, Sánchez-Gullón E, Muñoz-Rodríguez AF. Reproductive phenology and pre-dispersal fruit predation in Atriplex halimus L. (Chenopodiaceae). Bot Stud 2013;54:4.

4. Chikhi I, Allali H, Dib ME, Medjdoub H, Tabt B. Antidiabetic activity of aqueous leaf extract of Atriplex halimus L. (Chenopodiaceae) in streptozotocin-induced diabetic rats. Asian Pac J Trop Dis 2014;4:181-4.

5. Ort-90.ac J J, Mart90.ac J T C, Correal E, Simre B, Cenis JL. Genetic structure of Atriplex halimus populations in the Mediterranean Basin. Ann Bot 2005;95:827-34.

6. Abd El-Rahman HH, Mohamed MI, Gehad AE, Awadallah IM. Ameliorating the anti-nutritional factors effect in Atriplex halimus on sheep and goats by ensiling or polyethylene glycol supplementation. Int J Agric Biol 2006;8:766-9.
7. Nedjimia B, Daoud Y. Cadmium accumulationin Atriplex halimus subsp. schweinfurthii and its influence on growth, proline, root hydraulic conductivity and nutrient uptake. Flora 2009;204:316-24.

8. Kabbash A, Shoeib N. Chemical and biological investigation of some secondary metabolites in Atriplex halimus growing in Egypt. Nat Prod Commun 2012;7:1465-8.

9. Clauser M, Dall'Acqua S, Loi MC, Innocenti G. Phytochemical investigation on Atriplex halimus L. from Sardinia. Nat Prod Res 2013;27:1940-4.

10. Ozenda P. In: Flore Du Sahara. $2^{\text {nd }}$ ed. Paris: CNRS; 1983

11. Ziane L, Lazouni HA, Moussaoui A, Namidi N, Djellouli M, Belabbes A. Flavonoid from methanolic extract of Limoniastrum feei (girard) batt (Plumbaginaceae). Asian J Pharm Clin Res 2015;8:218-9.

12. Council of Europe. European Pharmacopoeia. $3^{\text {rd }}$ ed. Strasbourg: Council of Europe; 1997.

13. Bajalana I, Pirbalouti AG. Variation in antibacterial activity and chemical compositions of essential oil from different populations of myrtle. Ind Crops Prod 2014;61:303-7.

14. Haiyan G, Lijuan H, Shaoyu L, Chen Z, Ashraf MA. Antimicrobial, antibiofilm and antitumor activities of essential oil of Agastache rugosa from Xinjiang, China. Saudi J Biol Sci 2016;23:524-30.

15. Boudjedjou L, Ramdani M, Zeraib A, Benmeddour T, Fercha A. Chemical composition and biological activities of Algerian Santolina africana essential oil. Sci Afr 2019;4:e00090.

16. Bajer T, Silha D, Ventura K, Bajerovi P. Composition and antimicrobial activity of the essential oil, distilled aromatic water and herbal infusion from Epilobium parviflorum Schreb. Ind Crops Prod 2017;100:95-105.

17. Raimundo KF, Bortolucci WC, Glamolucci J, Sokoviu M, Gonoviucc JE, Linde GA, et al. Antifungal activity of Gallesia integrifolia fruit essential oil. Braz J Microbiol 2018;49 Suppl 1:229-35.

18. Esmaeili H, Karami A, Maggi F. Essential oil composition, total phenolic and flavonoids contents, and antioxidant activity of Oliveria decumbens Vent. (Apiaceae) at different phenological stages. J Cleaner Prod 2018;198:91-5.

19. Sajjadi MH, Amiri H. Chemical constituents of the essential oils of different stages of the growth of Stachys lavandulifolia Vahl. from Iran. Pak J Biol Sci 2007;10:2784-6.

20. Djellouli M, Benmehdi H, Mammeri S, Moussaoui A, Ziane L, Hamidi N. Chemical constituents in the essential oil of the endemic plant Cotula cinerea (Del.) from the Southwest of Algeria. Asian Pac J Trop Biomed 2015;5:10.

21. Hamidi N, Ziane L, Djellouli M, Lazouni HA. Chemical characterization by GC-MS from the aerial parts of Fagonia longispina (Zygophyllaceae). Asian J Pharm Clin Res 2016;9:152-3. 